Original Article

\title{
Chloroacetanilide herbicide-induced rat enterochromaffin cell tumors: a case study within the context of the IPCS framework, for analyzing the relevance of a cancer mode of action for humans
}

\author{
Midori Yoshida ${ }^{*}$ \\ ${ }^{1}$ Food Safety Commission, Cabinet Office of Japan, Akasaka Park Bld 22F, 5-2-20 Akasaka, Minato-ku, Tokyo 107-6122, Japan
}

\begin{abstract}
The WHO International Programme on Chemical Safety (IPCS) framework for analyzing the relevance of a cancer mode of action (MoA) for humans (IPCS cancer-HRF) is an application to assess human relevance of tumorigenic hazards found through rodent bioassays. The chloroacetanilide herbicides, butachlor and alachlor, induced enterochromaffin-like (ECL) cell tumors in rat stomachs, at the highest doses. This study analyzed the human relevance of this tumor by applying the IPCS cancer-HRF using published data. In a postulated MoA, early key events (KEs) included decreased mucosal thickness in the fundic region, due to reduced parietal cells. The following KEs included increased $\mathrm{pH}$ of gastric acid and hypergastrinemia, leading to enhanced cell proliferation and hyperplasia, and resulting in the outcome of an ECL cell tumor. The data showed consistencies in dose-response and temporal concordance with the KEs and specificity in the tumor response, providing strengthened evidence of the KEs. While the early KE was not the same, similar MoAs have already been established for omeprazole and ciprofloxacin. The integrated data indicated that the postulated MoAs were biologically plausible. Alternative MoAs were excluded.. Based on sufficient evidence, an MoA was established in rats. When addressing chemically inducible MoAs of human relevance, KEs of hypergastrinemia and trophic ECL cell hyperplasia were judged to not be qualitatively and quantitatively plausible in humans. The MoA in rats is unlikely to be present in humans; however, the potential effects on parietal cells cannot be excluded. Thus, the IPCS cancer-HRF is very useful for assessing human relevance. (DOI: 10.1293/tox.20210009; J Toxicol Pathol 2021; 34: 213-222)
\end{abstract}

Keywords: enterochromaffin-like cell tumors, chloroacetanilide herbicides, IPCS framework, human relevance, mode of action

\section{Introduction}

The chloroacetanilide herbicides, butachlor (IUPAC: $\mathrm{N}$-butoxymethyl-2-chloro-2', 6'-diethylacetanilide) and alachlor (IUPAC: 2-chloro-2',6'-diethyl- $N$-methoxymethylacetanilide), show chemical structure similarity, and are known to induce (at the highest dose tested) enterochromaffin-like (ECL) cell tumors in the glandular stomach in carcinogenicity studies on rats 1,2 (Table 1 ). ECL cell tumor induction in rodent bioassays has not been reported for other chloroacetanilide herbicides ${ }^{3-5}$. No genotoxicity has been reported for any chloroacetanilide herbicide, in an adequate battery of genotoxicity studies carried out in vitro and in vivo. Because ECL cell tumor induction by butachlor/

Received: 1 February 2021, Accepted: 3 March 2021

Published online in J-STAGE: 2 April 2021

*Corresponding author: M Yoshida

(e-mail: midori.yoshida.w2e@cao.go.jp)

(Supplementary material: refer to PMC https://www.ncbi.nlm.nih. gov/pmc/journals/1592/)

(C2021 The Japanese Society of Toxicologic Pathology

This is an open-access article distributed under the terms of the Creative Commons Attribution Non-Commercial No Derivatives (c) $($ (by-nc-nd) License. (CC-BY-NC-ND 4.0: https:// (c) ${ }_{\text {BY NC ND }}$ creativecommons.org/licenses/by-nc-nd/4.0/). alachlor has been assessed as an effect of a non-genotoxic carcinogen, the acceptable daily intakes (ADIs) of both the compounds have been specified as $0.01 \mathrm{mg} / \mathrm{kg}$ body weight/ day (bw/d) upon toxicological evaluation by the Food Safety Commission of Japan (FSCJ), the organization responsible for risk assessment of chemicals in foods in Japan.

To specify health-based guidance values for pesticide residues such as ADI, toxicity studies in compliance with Good Laboratory Practice (GLP) and in accordance with the guidelines of the Organization for Economic Cooperation and Development (OECD) or Ministry of Agriculture, Fishery and Forest (MAFF), have been requested. Recently, apart from these requested toxicity studies, mode of action (MoA) studies assessing the induced toxicity/carcinogenicity have also been conducted. MoA studies based on updated scientific knowledge are important for the interpretation of toxicity and/or carcinogenicity induced by a chemical. In particular, the consideration of an MoA of human relevance is crucial for dietary risk assessment of pesticide residues, because consumers have been taking in residue levels of pesticides through foods over the course of their entire lives.

Recently, the International Programme on Chemical Safety (IPCS) established a framework for analyzing the relevance of a cancer-/non-cancer MoA for humans (IPCS cancer-/non-cancer-HRF) ${ }^{6-8}$. This consists of a series of key 
events (KEs) along the causal pathway to cancer, identified using a weight-of-evidence approach, based on the criteria of Sir Bradfold Hill9. The Food and Agriculture Organization (FAO) and World Health Organization (WHO) Joint Meeting on Pesticide Residues (JMPR) has positively evaluated pesticide-induced cancer or non-cancer MoAs and their human relevance by applying the IPCS cancer-/noncancer-HRF10-22. Rodent liver tumor induction is the most popular example of applying the framework to toxicological evaluations of JMPR ${ }^{10-16,21}$. Recently, pydiflumetofeninduced liver tumors in male mice were assessed using the IPCS cancer-HRF ${ }^{21}$. The postulated MoA is constitutive androstane receptor-mediated liver tumor induction in mice. Various pieces of evidence on the KEs provided a high level of confidence that the postulated MoA was responsible for tumor outcomes in male mice. With regard to the human relevance of the postulated MoA, on the basis of the qualitative differences in the hepatocellular proliferation response to pydiflumenfen, it was established that this MoA is not relevant to humans ${ }^{21}$.

When the MoA of toxicity or tumor induced by a chemical is assessed using the IPCS cancer-/non-cancerHRF, adequate data, including evidence from open literature, are needed to clarify the MoA. For butachlor and alachlor, a number of MoA studies on stomach tumors have been conducted by the applicants, and the summaries of these studies have been published in their risk assessment reports to FSCJ1,2. In addition, ECL cell tumors in rats are typical tumors for which MoA and human relevance have already been investigated in cases of gastric acid secretion inhibitors such as omeprazole or other classes of chemicals such as ciprofibrate ${ }^{23-25}$. Therefore, it is predicted that adequate data are available for the assessment of the MoA of butachlor-/alachlor-induced ECL cell tumors using the IPCS cancer-HRF.

The purpose of this analysis was to clarify the MoA of butachlor- and alachlor-induced ECL cell tumors, and to assess their human relevance by applying the IPCS cancerHRF. All the data used in this study have been published. The author emphasizes that the views, thoughts, and opinions presented in this article are not necessarily those of FSCJ.

\section{Materials and Methods}

\section{Materials}

Two chloroacetanilide herbicides, butachlor and alachlor, were selected for the analysis because a number of MoA studies assessing the effects of these compounds on stomach tumor induction in rats have been conducted. The data analyzed included published reports for both the compounds. Major evidence were obtained from the risk assessment reports for both the compounds to $\mathrm{FSCJ}^{1,2}$, because the toxicological evaluations of both the compounds were conducted by toxicology experts using toxicity studies compliant with GLP and in accordance with guidelines authorized by the OECD or MAFF. Open literature written by the company's researchers ${ }^{26,27}$ was also used as supportive information for the MoA.

Butachlor and alachlor have similar chemical structures and toxicological profiles ${ }^{1,2}$. The toxicological targets of both the compounds include the liver, nasal epithelium, glandular stomach, and thyroid. Liver, stomach, and thyroid tumors are also induced by both the compounds. Reproductive toxicity, teratogenicity, or genotoxicity relevant to humans has not been observed in case of either of the com-

Table 1. Histopathology of the Stomach in Chronic/Carcinogenicity Studies Carried out on Rats Treated with Butachlor and Alachlor

\begin{tabular}{|c|c|c|c|c|c|c|c|c|}
\hline \multirow{2}{*}{ Butachlor (SD rats) } & \multicolumn{4}{|c|}{ Male } & \multicolumn{4}{|c|}{ Female } \\
\hline & & & & & & & & \\
\hline Concentration (ppm) & 0 & 100 & 1,000 & 3,000 & 0 & 100 & 1,000 & 3,000 \\
\hline Dose (mg/kg bw/d) & 0 & 4.5 & 45.6 & 139 & 0 & 5.7 & 58.5 & 190 \\
\hline No. of rats examined & 78 & 80 & 80 & 79 & 80 & 78 & 80 & 80 \\
\hline Enterochromaffin cell hyperplasia (a) & 0 & 0 & 0 & 1 & 0 & 0 & 0 & 4 \\
\hline ECL cell tumor, benign (a) & 0 & 0 & 0 & 0 & 0 & 0 & 0 & 1 \\
\hline ECL cell tumor, malignant (a) & 0 & 0 & 0 & 1 & 0 & 0 & 0 & $22 *$ \\
\hline Total incidence of ECL cell tumor & 0 & 0 & 0 & 1 & 0 & 0 & 0 & $23^{*}$ \\
\hline Alachlor (Long-Evans rats) & & & & & & & & \\
\hline Dose $(\mathrm{mg} / \mathrm{kg} \mathrm{bw} / \mathrm{d})$ & 0 & 14 & 42 & 126 & 0 & 14 & 42 & 126 \\
\hline No. of rats examined & 49 & 50 & 50 & 50 & 50 & 50 & 50 & 49 \\
\hline Hyperplasia/gastritis & 0 & 0 & 0 & 1 & 0 & 0 & 0 & 0 \\
\hline Enterochromaffin cell hyperplasia (a) & 0 & 0 & 0 & 1 & 0 & 0 & 0 & 0 \\
\hline ECL cell tumor, malignant (a) & 0 & 0 & 0 & $10 *$ & 0 & 0 & 0 & 20 \\
\hline Osteosarcoma & 0 & 0 & 0 & $1(b)$ & 0 & 0 & 0 & $2(b)$ \\
\hline Mixed sarcoma & 0 & 0 & 0 & $4(b)$ & 0 & 0 & $1(\mathrm{~b})$ & $1(b)$ \\
\hline Total incidence in the glandular-stomach & 0 & 0 & 0 & $15^{*}$ & 0 & 0 & 1 & $23^{*}$ \\
\hline
\end{tabular}

(a) Diagnosis post peer review; (b) original diagnosis because peer review was not conducted; *Statistically significant difference from the control value at $\mathrm{p}<0.01$.

Reference sources ${ }^{1-2}$. 
pounds. The list of studies used in the current analysis of both the compounds is provided in Supplementary Table 1.

\section{Methods}

Analysis process using the IPCS cancer-HRF

The IPCS cancer-HRF has been described in several publications $^{3-5}$. Briefly, the IPCS framework is mainly composed of two parts. The first part involves steps to check the sufficiency of the weight of evidence available to establish a MoA based on animal data, and the second part evaluates the human applicability of the proposed MoA found in animal experiments.

The first part has 9 steps to check causalities in animals, which are as follows:

1) Postulated MoA;

2) KEs and associated critical parameters;

3) Dose-response concordance;

4) Temporal association;

5) Strength, consistency, and specificity of the association of the tumor response with the KEs

6) Biological plausibility and coherence;

7) Possible alternative MoAs;

8) Uncertainties, inconsistencies, and data gaps;

9) Conclusion about the MoA.

The second part presents a four-step approach to address a series of three questions and leads to a documented and logical conclusion regarding the human relevance of the MoA underlying animal tumors. The four-step approach is as follows:

1) Is the weight of evidence sufficient to establish an MoA in animals?

2) Can the human relevance of the MoA be reasonably excluded on the basis of fundamental, qualitative differences in the KEs between the experimental animals and humans?

3) Can the human relevance of the MoA be reasonably excluded on the basis of quantitative differences in either the kinetics or dynamic factors between the experimental animals and humans?

4) Conclusion: statement of confidence, analysis, and implications.

\section{Results and Discussion}

\section{Postulated mode of action and key events}

Based on the integrated evidence of the MoA published in the risk assessment reports and the data from several open literature on butachlor and alachlor, an MoA of butachlor- and alachlor-mediated ECL cell tumor induction was postulated, as given below ${ }^{1,2,26,27}$ :

The initial KE is that high-dose treatment with alachlor/butachlor causes a marked decrease in the parietal cells of rat glandular stomachs ${ }^{1,2,27}$. Post absorption, butachlor/alachlor reduce the parietal cells in the fundic region of the glandular stomach. The reduced number of parietal cells leads to decreased mucosal thickness of the fundic region and mucosal atrophy. The prolonged reduction of parietal cells causes consistent inhibition of acid secretion, which increases the $\mathrm{pH}$ of gastric acid. Subsequently, hyperplasia of antral cells and marked hypergastrinemia are observed. Hypergastrinemia stimulates enterochromaffin cell proliferation in the fundus, leading to ECL cell hyperplasia. The final outcome is ECL cell tumor formation. The postulated MoA is shown in Fig. 1.

KEs in the postulated MoA are as follows:

- A reduced number of parietal cells in the fundic region of the glandular stomach leads to decreased thickness of the fundic region and mucosal atrophy;

- Increased pH of gastric acid, due to inhibition of acid secretion;

- Hypergastrinemia;

- Increased activity of enterochromaffin cell proliferation;

- ECL cell hyperplasia.

Relevant data for the assessment of the MoA hypothesis for stomach tumors induced by butachlor and alachlor

Available data for the assessment of the IPCS-HRF analysis listed in Supplementary Table 1 were considered adequate, because information on the effect of dose-response and duration of treatment on the KEs/outcome could be accessed through the data.

\section{Concordance of dose-response}

The relationship between the KEs of ECL cell tumors and inducible doses of KEs was analyzed (Table 2). Based on the data in Tables 1 and 2, ECL cell tumors were observed for males and females at 139 and $190 \mathrm{mg} / \mathrm{kg} \mathrm{bw} / \mathrm{d}$ butachlor, respectively; effects were observed with $126 \mathrm{mg} /$ $\mathrm{kg} \mathrm{bw} / \mathrm{d}$ alachlor for both the sexes in the carcinogenicity studies. These doses were the highest, indicating that the carcinogenic doses of both the compounds were over 100

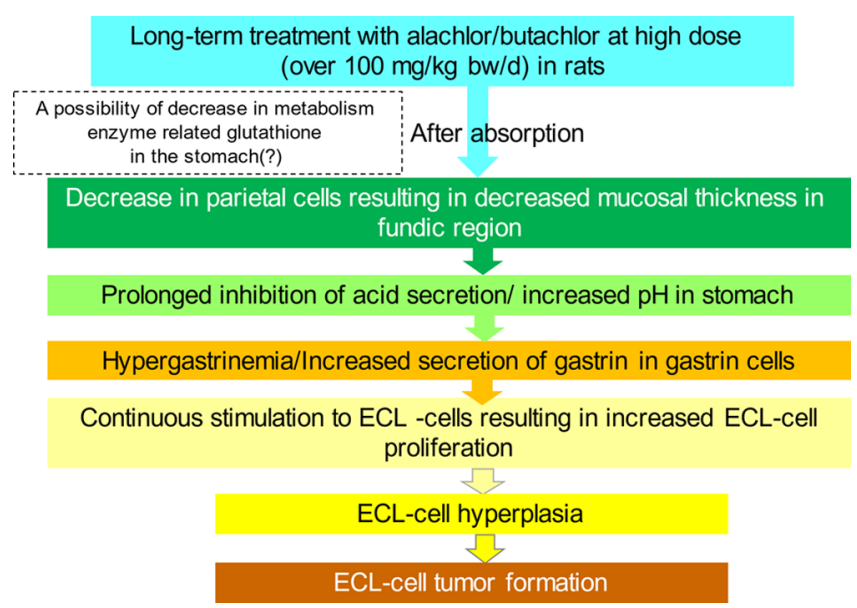

Fig. 1. Postulated MoA: ECL cell tumor induced by alachlor/butachlor and KEs. KEs, key events; MoA, mode of action;ECL cell, enterochromaffin-like cell; $\mathrm{mg} / \mathrm{kg} \mathrm{bw} / \mathrm{d}, \mathrm{mg} / \mathrm{kg}$ body weight per day. 
$\mathrm{mg} / \mathrm{kg}$ bw/d.

Most KEs were observed at the same doses as the carcinogenic doses in case of both the compounds, except the reduction in the parietal cell number, decreased mucosal thickness, and mucosal atrophy. These early KEs were induced at lower doses than the carcinogenic dose, which was the highest dose tested for both the compounds. The doseresponse results were considered reasonably concordant, because the early events cannot occur at doses higher than the carcinogenic dose.

\section{Temporal association}

The temporal concordance for the events associated with the fundic changes, such as decreased mucosal thickness or reduced number of parietal cells, is predicted to occur early following exposure to butachlor/alachlor after their absorption. A summary of the temporal associations is presented in Table 3.

The available data for each compound was not considered sufficient for the assessment of temporal concordance. However, a number of similarities, such as toxicological profiles, chemical structure, and postulated MoA, are known for butachlor and alachlor ${ }^{1,2}$. Therefore, the data for both the compounds were integrated to assess temporal associations. As a result, the earliest KE found was decreased mucosal thickness of the fundic region, which was observed $30 \mathrm{~d}$ post commencement of treatment. This change was consistent for $2 \mathrm{yr}$. Decreased gastric acid production and increased plasma/serum gastrin levels were found at $1 \mathrm{yr}$ (alachlor) and $180 \mathrm{~d}$ (butachlor/alachlor), although no measurements were conducted before these timings. Increased proliferation activity of ECL cells, a gastrin tropic event, was observed at $60 \mathrm{~d}$ (butachlor) and $120 \mathrm{~d}$ (alachlor), which was not observed until $30 \mathrm{~d}$ (butachlor) and $60 \mathrm{~d}$ (alachlor). ECL cell hyperplasia was detected at $1 \mathrm{yr}$, indicating late $\mathrm{KE}$ in the MoA. ECL cell tumor formation was initiated at $1 \mathrm{yr}$ in case of alachlor and at $2 \mathrm{yr}$ in case of butachlor. Overall, an outline of the temporal association can be drawn from the integrated data of both the compounds.

\section{Strength, consistency, and specificity of the associa- tion of tumor response with KEs}

The associations between tumor response and KEs are summarized in Table 4. For butachlor and alachlor, all the KEs were observed at the same or lower doses as those of ECL cell tumor formation, the outcome of the MoA. The evidence on dose-response indicated consistency of the association of the tumor response with the KEs. In the analysis of temporal concordance, KEs occurred in chronological order. Early KEs, such as decreased thickness of the fundic region due to a reduction in parietal cell number, were consistently found to occur earlier than the other KEs, such as increased $\mathrm{pH}$ of gastric acid and increased serum gastrin level, resulting in increased ECL cell proliferation and ECL cell hyperplasia. ECL cell tumors were formed after $1 \mathrm{yr}$ of treatment with both the compounds. Recovery from ECL cell proliferation was observed in case of butachlor. The results of dose-response and temporal concordance

Table 2. Summary of the dose-response Relationship of KEs in ECL Cell Tumor Induction

Dose levels (mg/kg bw/d)

\begin{tabular}{|c|c|c|c|c|}
\hline Butachlor & Dose range in which a KE-related change was observed & $4.5-6.64$ & $45.5-66.1$ & $139-213$ \\
\hline $\mathrm{KE}$ & Decreased parietal cell number & $\mathrm{NE}$ & $\begin{array}{l}\text { Yes, but not } \\
\text { significant }\end{array}$ & Yes \\
\hline $\mathrm{KE}$ & Decreased mucosal thickness & No & No & Yes \\
\hline $\mathrm{KE}$ & Mucosal atrophy & $\mathrm{NE}$ & Yes & Yes \\
\hline $\mathrm{KE}$ & Increased $\mathrm{pH}$ of gastric acid & No & No & Yes \\
\hline $\mathrm{KE}$ & Decreased gastric acid production & No & Increasing trend & Yes \\
\hline $\mathrm{KE}$ & Increased serum gastrin & $\mathrm{NE}$ & No & Yes \\
\hline $\mathrm{KE}$ & Increased activity of cell proliferation of enterochromaffin cells & $\mathrm{NE}$ & Yes & Yes \\
\hline $\mathrm{KE}$ & ECL cell hyperplasia & No & No & Yes \\
\hline Outcome & ECL cell tumor induction & No & No & Yes \\
\hline \multicolumn{5}{|l|}{ Alachlor } \\
\hline & & 14 & 42 & 126 \\
\hline $\mathrm{KE}$ & Decreased parietal cell number & $\mathrm{NE}$ & $\mathrm{NE}$ & Yes \\
\hline $\mathrm{KE}$ & Decreased mucosal thickness & No & No & $\mathrm{NE}$ \\
\hline $\mathrm{KE}$ & Mucosal atrophy & $\mathrm{NE}$ & Yes & Yes \\
\hline $\mathrm{KE}$ & Decreased gastric acid production & $\mathrm{NE}$ & $\mathrm{NE}$ & $\mathrm{NE}$ \\
\hline $\mathrm{KE}$ & Increased serum gastrin & $\mathrm{NE}$ & No & NE \\
\hline $\mathrm{KE}$ & Increased activity of cell proliferation of enterochromaffin cells & $\mathrm{NE}$ & No & Yes (a) \\
\hline $\mathrm{KE}$ & ECL cell hyperplasia & No & No & Yes \\
\hline Outcome & ECL cell tumor induction & No & No & Yes \\
\hline
\end{tabular}

KE:key event; NE: not examined at these doses; $\mathrm{mg} / \mathrm{kg}$ bw/d: $\mathrm{mg} / \mathrm{kg}$ body weight per day; (a) increased cell proliferation activity was also observed at the dose of $252 \mathrm{mg} / \mathrm{kg}$ bw/d in females.

Reference sources ${ }^{1-2,26-27}$. 
were reproducible in studies conducted using different experimental designs (Supplementary Table 1). The consistent temporal concordance in case of alachlor was not clearer than that in case of butachlor; however, integrated data from both the compounds indicated consistency of temporal concordance. Taken together, evidence on the consistency of dose-response and temporal concordance, as confirmed by multiple studies, supports the strong association of KEs with ECL cell tumors.

There was clear evidence of the specificity of ECL cell tumor formation in rats (Table 5). Butachlor or alachlor did not show any associated effects on ECL cell tumor formation in mice and dogs. A strain difference was also reported in rats; because of the decreased mucosal thickness of the fundic region, ECL cell proliferation of the glandular stomach or ECL cell tumor induction was not found in Fischer rats (Supplementary Table 1).

\section{Biological plausibility and coherence}

A comparison of the KEs between butachlor/alachlor and other compounds is summarized in Table 5. ECL cell tumors in rats are induced by other chemicals, such as omeprazole, a proton pump inhibitor, and ciprofloxacin, a potent lipidemic compound. ECL cell tumor induction by both the compounds was caused by the same MoA (Table 5): the early KE was a thickening of mucosa in the fundic stomach by blocking gastric acid secretion in the parietal cells. The following KEs included an increase in the $\mathrm{pH}$ of gastric acid, increased serum gastrin levels, and increased ECL cell proliferation activity, resulting in ECL cell hyperplasia and the final outcome of ECL cell tumors ${ }^{23-25,28}$. Although the early $\mathrm{KE}$ of the omeprazole/ciprofibrate MoA was different from that of butachlor/alachlor, the consequent KEs and the final outcome were common between omeprazole/ciprofibrate and butachlor/alachlor.

The species specificity for omeprazole/ciprofloxacininduced ECL cell tumor formation is also known. There is no definitive result that provides a reason for the species sensitivity in rats, but the anatomical or physiological specificity of the rat stomachs might be involved. In rats, ECL cell distribution in the fundic region of the glandular stomach is dense, and normal serum/plasma gastrin levels are high ${ }^{24-26}$. Therefore, the postulated MoA and its KEs observed in a number of studies on both the compounds are considered biologically plausible and coherent.

\section{Alternative MoAs}

One alternative, MoA, is genotoxicity, including DNA reactivity. However, butachlor and alachlor showed no genotoxicity, in an adequate number of genotoxicity tests carried out in vitro and in vivo ${ }^{1,2}$. In addition, in the initiation-promotion assays of both the compounds, they showed no effect as initiators ${ }^{1,2}$. Therefore, a genotoxicity-based MoA was excluded from the analysis.

The next alternative MoA is direct damage to the stomach mucosa. If butachlor or alachlor has the potential to directly damage the stomach, any inflammatory changes that react to the damage, such as an erosion or ulceration,

Table 3. Summary of the Temporal Association of KEs in ECL Cell Tumor Induction

\begin{tabular}{|c|c|c|c|c|c|c|c|c|}
\hline & Finding & & & & Duration & & & \\
\hline & & $10-14 \mathrm{~d}$ & $30 \mathrm{~d}$ & $60 \mathrm{~d}$ & $120 \mathrm{~d}$ & $180 \mathrm{~d}$ & $1 \mathrm{yr}$ & $2 \mathrm{yr}$ \\
\hline Butachlor & & & & & & & & \\
\hline $\mathrm{KE}$ & Decreased parietal cell number & $\mathrm{NE}$ & $\mathrm{NE}$ & $\mathrm{NE}$ & $\mathrm{NE}$ & NE & Yes & $\mathrm{NE}$ \\
\hline $\mathrm{KE}$ & Decreased mucosal thickness & No & Yes & Yes & Yes & Yes & Yes & Yes \\
\hline $\mathrm{KE}$ & Mucosal atrophy & $\mathrm{NE}$ & $\mathrm{NE}$ & $\mathrm{NE}$ & $\mathrm{NE}$ & $\mathrm{NE}$ & Yes & Yes \\
\hline $\mathrm{KE}$ & Increased $\mathrm{pH}$ of gastric acid & $\mathrm{NE}$ & $\mathrm{NE}$ & $\mathrm{NE}$ & $\mathrm{NE}$ & $\mathrm{NE}$ & $\mathrm{NE}$ & Yes \\
\hline $\mathrm{KE}$ & Decreased gastric acid production & $\mathrm{NE}$ & NE & $\mathrm{NE}$ & $\mathrm{NE}$ & $\mathrm{NE}$ & $\mathrm{NE}$ & Yes \\
\hline $\mathrm{KE}$ & Increased serum gastrin & $\mathrm{NE}$ & $\mathrm{NE}$ & $\mathrm{NE}$ & $\mathrm{NE}$ & Yes & Yes & Yes \\
\hline $\mathrm{KE}$ & Increased activity of cell proliferation of enterochromaffin cells & No & No & Yes & Yes & Yes & Yes & Yes \\
\hline $\mathrm{KE}$ & ECL cell hyperplasia & No & No & No & No & No & No & Yes \\
\hline Outcome & ECL cell tumor induction & No & No & No & No & No & No & Yes \\
\hline Alachlor & & & & & & & & \\
\hline $\mathrm{KE}$ & Decreased parietal cell number & $\mathrm{NE}$ & $\mathrm{NE}$ & $\mathrm{NE}$ & $\mathrm{NE}$ & $\mathrm{NE}$ & $\mathrm{NE}$ & Yes \\
\hline $\mathrm{KE}$ & Decreased mucosal thickness & $\mathrm{NE}$ & $\mathrm{NE}$ & $\mathrm{NE}$ & $\mathrm{NE}$ & $\mathrm{NE}$ & Yes & $\mathrm{NE}$ \\
\hline $\mathrm{KE}$ & Mucosal atrophy & $\mathrm{NE}$ & $\mathrm{NE}$ & $\mathrm{NE}$ & $\mathrm{NE}$ & $\mathrm{NE}$ & Yes & $\mathrm{NE}$ \\
\hline $\mathrm{KE}$ & Increased $\mathrm{pH}$ of gastric acid & $\mathrm{NE}$ & $\mathrm{NE}$ & $\mathrm{NE}$ & $\mathrm{NE}$ & $\mathrm{NE}$ & Yes & $\mathrm{NE}$ \\
\hline $\mathrm{KE}$ & Decreased gastric acid production & $\mathrm{NE}$ & $\mathrm{NE}$ & $\mathrm{NE}$ & $\mathrm{NE}$ & $\mathrm{NE}$ & Yes & $\mathrm{NE}$ \\
\hline $\mathrm{KE}$ & Increased serum gastrin & $\mathrm{NE}$ & $\mathrm{NE}$ & NE & $\mathrm{NE}$ & Yes & $\mathrm{NE}$ & $\mathrm{NE}$ \\
\hline $\mathrm{KE}$ & Increased activity of cell proliferation of enterochromaffin cells & No (a) & $\mathrm{NE}$ & No (a) & Yes & $\mathrm{NE}$ & $\mathrm{NE}$ & $\mathrm{NE}$ \\
\hline $\mathrm{KE}$ & ECL cell hyperplasia & No & No & No & No & No & No & Yes \\
\hline Outcome & ECL cell tumor induction & No & No & No & No & No & Yes & Yes \\
\hline
\end{tabular}

KE: key event; d: days; yr: year(s); NE: not examined; ECL cell: enterochromaffin-like cell; (a) the cell proliferation activity increased at the dose of $252 \mathrm{mg} / \mathrm{kg}$ bw/d, which was higher than $126 \mathrm{mg} / \mathrm{kg}$ bw/d, the carcinogenic dose, from 10 days onwards. At $126 \mathrm{~m} / \mathrm{kg}$ bw/d, the carcinogenic dose, the increased was observed from oedy weight per day from 120 days onwards.

Reference sources ${ }^{1-2,27}$. 
Table 4. Evidence to Show the Strength, Consistency, and Specificity of the Association of Tumor Response with KEs

\begin{tabular}{|c|c|c|c|c|}
\hline $\begin{array}{l}\text { Chronological order of KEs in the } \\
\text { postulated MoA }\end{array}$ & Evidence & $\begin{array}{l}\text { The lowest } \\
\text { dose observed } \\
\text { (mg/kg bw/d) }\end{array}$ & $\begin{array}{l}\text { When was the } \\
\text { effect observed? }\end{array}$ & $\begin{array}{l}\text { No. of studies in } \\
\text { which reproducibility } \\
\text { was found }\end{array}$ \\
\hline \multicolumn{5}{|l|}{ Butachlor } \\
\hline \multirow{3}{*}{ Early KE } & Decreased mucosal thickness & 213 & From $30 \mathrm{~d}$ & \multirow{3}{*}{5} \\
\hline & Decreased parietal cell number & 66 & 12 months & \\
\hline & Mucosal atrophy & 139 & From 1 yr & \\
\hline \multirow{2}{*}{ Post mucosal change } & Decreased gastric acid production & 66.1 & $1 \mathrm{yr}$ & \multirow{2}{*}{2} \\
\hline & Increased $\mathrm{pH}$ of gastric acid & 213 & $2 \mathrm{yr}$ & \\
\hline Post decreased gastric acid production & Increased serum gastrin & 213 & From $180 \mathrm{~d}$ & 1 \\
\hline Post hypergastrinemia & Increased activity of ECL cell proliferation & 213 & From $60 \mathrm{~d}$ & 2 \\
\hline Post prolonged cell proliferation & ECL cell hyperplasia & 213 & $2 \mathrm{yr}$ & 1 \\
\hline Outcome & ECL cell tumor induction & 213 & $2 \mathrm{yr}$ & 2 \\
\hline \multicolumn{2}{|l|}{ Did the evidence show recovery? } & 213 & $60 \mathrm{~d}$ & 1 \\
\hline \multirow{3}{*}{\multicolumn{2}{|c|}{$\begin{array}{l}\text { Is the dose consistently the same as or lower than the carcinogenic dose? } \\
\text { Did the KEs occur consistently and in chronological order? } \\
\text { Did the evidence show reproducibility? }\end{array}$}} & Yes & & \\
\hline & & \multirow{2}{*}{\multicolumn{2}{|c|}{ Yes }} & \\
\hline & & & & Yes \\
\hline \multicolumn{5}{|l|}{ Alachlor } \\
\hline \multirow{3}{*}{ Early KE } & Decreased mucosal thickness & 126 & From 1 yr & \multirow{3}{*}{3} \\
\hline & Decreased parietal cell number & 126 & $2 \mathrm{yr}$ & \\
\hline & Mucosal atrophy & 126 & From $1 \mathrm{yr}$ & \\
\hline Post mucosal change & Increased $\mathrm{pH}$ of gastric acid & 126 & $1 \mathrm{yr}$ & 1 \\
\hline Post decreased gastric acid production & Increased serum gastrin & 126 & From $180 \mathrm{~d}$ & 1 \\
\hline Post hypergastrinemia & Increased activity of ECL cell proliferation & 126 & From $120 \mathrm{~d}$ & 1 \\
\hline Post prolonged cell proliferation & ECL cell hyperplasia & 126 & $2 \mathrm{yr}$ & 1 \\
\hline Outcome & ECL cell tumor induction & 126 & From $1 \mathrm{yr}$ & 2 \\
\hline \multicolumn{2}{|c|}{ Is the dose consistently the same as or lower than the carcinogenic dose? } & Yes & & \\
\hline \multicolumn{2}{|c|}{ Did the KEs occur consistently and in chronological order? } & & $\begin{array}{l}\text { Not clear due } \\
\text { to only one } \\
\text { measurement }\end{array}$ & \\
\hline
\end{tabular}

KE: key event; MoA: mode of action; mg/kg bw/d: mg/kg bodyweight per day; ECL cell: enterochromaffin-like cell; d: days; yr: year(s). Reference sources ${ }^{1-2,26-27}$.

should have been induced in the surface epithelium of the stomach. However, no inflammatory changes were observed for either compound ${ }^{1,2}$. In addition, radiolabels of both the compounds were not found to be distributed in the stomach during the absorption, distribution, metabolism and excretion (ADME) studies 1, 2, 27. Therefore, this MoA was also excluded.

Toxic metabolite formation in the stomach should also be considered, because butachlor and alachlor are known to induce species-specific nasal tumors via toxic metabolite formation in the nasal cavity. In the ADME studies, radiolabels of both the compounds were not found to be distributed in the stomach. Therefore, this MoA was also excluded 1,2,27.

ECL cell tumors are known to be induced in rats by medical drugs such as omeprazole, to inhibit gastric acid secretion, as described above. The early KE of this MoA was morphologically characterized as a thickened fundic region ${ }^{29}$. Although the other KEs of these blocking enzymes were similar to those of butachlor and alachlor, the early KE was different 28 .

\section{Uncertainties, inconsistencies, and data gaps}

The most important uncertainty is that the initial molecular KE that induces parietal cell number reduction remained undetermined in case of butachlor and alachlor. This $\mathrm{KE}$ was different from that of omeprazole and ciprofloxacin. There have been several studies on glutathione measurement in the liver or stomach with butachlor/alachlor; however, no clear results were obtained to provide evidence that glutathione depletion occurs in the fundic region or active metabolite formation (Supplementary Table 1). The MoA of the initial KE leading to reduced parietal cell counts/decreased mucosal thickness of the fundic region should be clarified in rats. If there is no evidence showing the MoA, these effects observed as initial KE and leading KE should be identified as the effects relevant to humans.

Data gaps in temporal association existed because of the inappropriate timing of measurements of KEs. The chronological occurrence of alachlor was not clear compared to that of butachlor. However, as described in the temporal association, the outline of the temporal association could be drawn from the integrated data of both the compounds. No data inconsistency was observed. 
Table 5. Species Comparison of Gastric Changes Induced by Butachlor/Alachlor and Other Chemicals during ECL Cell Tumor Induction in Rats, as well as, in the Anatomy/Physiology of the Stomach

\begin{tabular}{|c|c|c|c|c|c|}
\hline Evidence & Rat & Mouse & Dog & $\begin{array}{l}\text { Monkey/ } \\
\text { marmoset }\end{array}$ & Human \\
\hline \multicolumn{6}{|l|}{ Butachlor $^{1-2,27 a}$} \\
\hline Decreased mucosal thickness & Yes & No & No & No & \\
\hline Increased $\mathrm{pH}$ of gastric acid & Yes & $\mathrm{NE}$ & $\mathrm{NE}$ & $\mathrm{NE}$ & \\
\hline Increased serum/plasma gastrin level & Yes & NE & NE & $\mathrm{NE}$ & \\
\hline ECL cell proliferation & Yes & No & No & No & \\
\hline ECL cell hyperplasia & Yes & No & No & NE & \\
\hline ECL cell tumor & Yes & No & No & NE & \\
\hline \multicolumn{6}{|l|}{ Omeprazole $^{23,28 a}$} \\
\hline Gastric mucosa thickening & Yes & NE & Yes* & NE & \\
\hline Increased serum/plasma gastrin level & Yes, marked & NE & $\mathrm{NE}$ & $\mathrm{NE}$ & \\
\hline ECL cell hyperplasia & Yes & NE & Yes* & NE & \\
\hline ECL cell tumor & Yes & No & No & NE & \\
\hline \multicolumn{6}{|l|}{ Ciprofibrate $24-25 a$} \\
\hline Gastric mucosa change & Yes & No & NE & No & \\
\hline Increased serum/plasma gastrin level & Yes & No & No & No & No \\
\hline Morphological change in ECL cells & Yes & No & NE & No & \\
\hline ECL cell hyperplasia & Yes & No & NE & No & \\
\hline ECL cell tumor & Yes & No & $\mathrm{NE}$ & NE & \\
\hline \multicolumn{6}{|l|}{ Anatomical/physiological profiles } \\
\hline ECL cell density $23,26 \mathrm{a}$ & High & NE & NE & NE & Low \\
\hline Normal serum gastrin level $(\mathrm{pg} / \mathrm{mL})^{24-26,31}$ & $170-360$ & $70-110$ & $\mathrm{NE}$ & $47-90$ & $40-180$ \\
\hline Serum gastrin level of patient with gastrinoma $(\mathrm{pg} / \mathrm{mL})^{31}$ & & & & & $<1,000$ \\
\hline Serum gastrin level of patient with atrophy gastritis $(\mathrm{pg} / \mathrm{mL})^{31}$ & & & & & Increase, $<1,000$ \\
\hline
\end{tabular}

ECL cell: enterochromaffin-like cell; a, data obtained from reference; *, This effect was observed at a 10-fold higher range than the same effective dose in rats. NE: not examined.

\section{Assessment of the postulated MoA}

The data provide adequate support for a non-genotoxic threshold-based MoA for the development of ECL cell tumors in rats with chronic exposure to butachlor or alachlor, 2. The KEs for the MoA were identified and supported by consistent data on dose-response and temporal concordance. In addition, this MoA is similar to the MoA of ECL cell tumor induction by omeprazole and ciprofloxacin in rats, except for the difference in the early KE. Taken together, the postulated MoA of ECL cell tumor induction was strongly supported by consistent evidence of KE associated with the tumor. 3.10. Human relevance of the postulated MoA Section 3.10 describes Step 2 of the IPCS cancer-HRF.

\section{Is the weight of evidence sufficient to establish the MoA in animals?}

Yes, the toxicological data support a non-genotoxic, threshold-based MoA for the development of ECL cell tumors in the glandular stomach of rats post chronic and high-dose exposure to butachlor or alachlor. The weight of evidence supports an increased $\mathrm{pH}$ of gastric acid and increased gastrin-tropic continuous ECL cell proliferation activity. The early KE is considered a different MoA from the known MOAs of omeprazole and ciprofloxacin in rats.
Can the human relevance of the MoA be reasonably excluded on the basis of fundamental/qualitative differences in key events between humans and animals?

Qualitatively, continuously higher plasma/serum gastrin levels may pose a potential risk of ECL cell tumors in the stomach of humans, because hypergastrinemia is considered to induce ECL cell hyperplasia in patients with gastrinoma or chronic atrophic gastritis ${ }^{30}$. In humans, the increased levels of serum gastrin are higher in patients with gastrinomas than in those with atrophic gastritis ${ }^{31}$. In addition, carcinoid tumors or gastrinomas have rarely been detected in humans. Even when hypergastrinemia is marked and prolonged, such as in patients with Zollinger-Ellison syndrome, gastric carcinoids are $\operatorname{rar}^{28}$. When considering the inducible possibility of hypergastrinoma leading to increased activity of ECL cells by any treatment, it is widely understood to be an effect of exaggerated pharmacodynamic activity not directly relevant to the therapeutic dose of these drugs, such as omeprazole ${ }^{28}$. KEs were not observed in animals other than those treated with omeprazole or ciprofloxacin (Table 6). Anatomical and physiological specificities exist in the stomach of rats. Therefore, MoA in rats is unlikely to lead to ECL cell tumors in humans at levels of exposure arising from pesticide residues in food. 
Can the human relevance of the MoA be reasonably excluded on the basis of quantitative differences in KEs between the experimental animals and humans?

Yes. As mentioned above, the human relevance of the MoA can reasonably be excluded based on qualitative differences in the toxicology data. Margins between inducible doses of the ECL cell tumor (over $100 \mathrm{mg} / \mathrm{kg}$ bw/d for both the compounds) and an ADI of $0.01 \mathrm{mg} / \mathrm{kg} \mathrm{bw} / \mathrm{d}$ for both the compounds, which are health-based guidance values for chronic exposure, were over $10,000^{1,2}$. Consumers are not predicted to be exposed to butachlor/alachlor at such dose levels via food.

\section{Statement of confidence, analysis, and implications of IPCS cancer-HRF}

There is sufficient evidence to establish the ECL cell tumor MoA for butachlor/alachlor in rats. There are no human data on chronic exposure to butachlor/alachlor, and there is no evidence on chemicals with the same MoA as butachlor/alachlor-induced gastrin-tropic ECL cell proliferation in humans, as the early KEs were not the same. When IPCS cancer-HRF was applied to ECL cell tumor induction by butachlor and alachlor, the MOA established in rats was reasonably excluded from human relevance, both qualitatively and quantitatively. Based on the MoA, ECL cell induction in rats was found to be irrelevant to humans. Each step in the assessment of the postulated MoA in rats for human relevance is shown in Fig. 2.

\section{Conclusion of the current analysis and applicability of IPCS cancer-HRF}

The current study indicated that the MoA of ECL cell tumors induction by butachlor and alachlor and its relevance to humans could be analyzed using the IPCS cancer-HRF. The MoA of ECL cell tumors induced in rats is not considered to be extrapolatable to humans. The hazard potential that the exposure to these compounds induces a change in the parietal cell number (an early KE) in humans cannot be
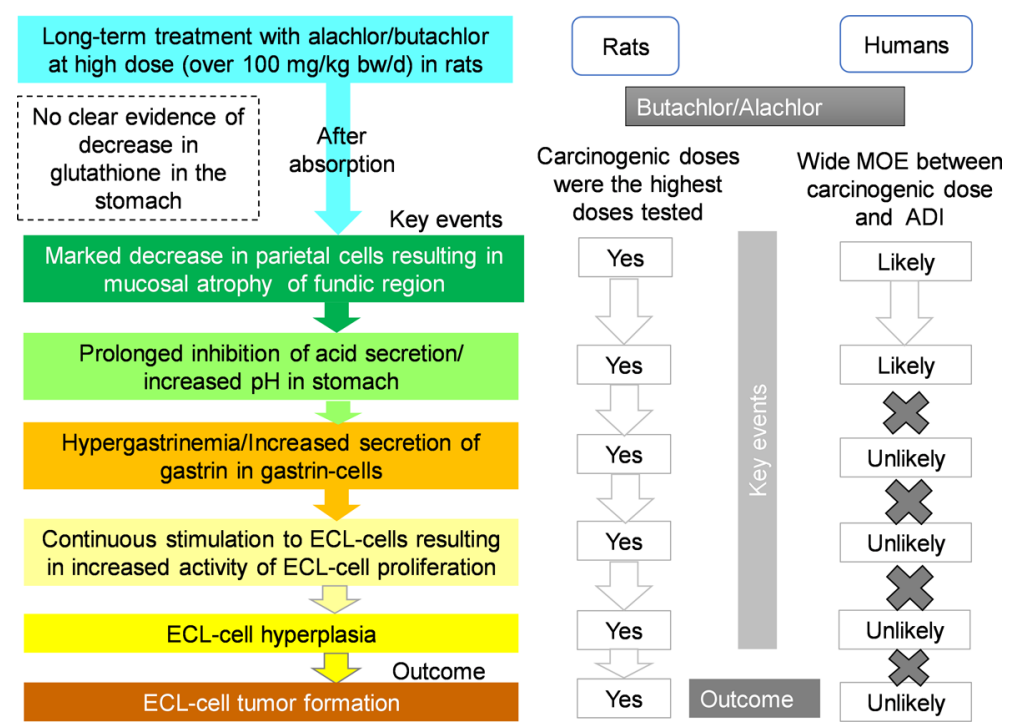

Fig. 2. Human relevance of MoA in butachlor-/alachlor-induced ECL cell tumor induction. MoA, mode of action; ECL cell, enterochromaffin-like cell; $\mathrm{mg} / \mathrm{kg}$ bw/d, $\mathrm{mg} / \mathrm{kg}$ body weight per day.

Table 6. Human Relevance of KEs in the Postulated MoA of ECL Cell Tumor Induction by Butachlor and Alachlor

\begin{tabular}{|c|c|c|c|c|}
\hline & KE-related change & Rat & Human & Comments \\
\hline $\mathrm{KE}$ & Decreased parietal cell number & Yes & Likely & \multirow{2}{*}{$\begin{array}{l}\text { If gastric acid secretion is reduced in parietal cells, any reaction } \\
\text { may occur in the fundic mucosa as a hazard. The reactive change } \\
\text { was species-specific for omeprazole or ciprofibrate. }\end{array}$} \\
\hline $\mathrm{KE}$ & $\begin{array}{l}\text { Decreased mucosal thickness/ } \\
\text { mucosal atrophy }\end{array}$ & Yes & Likely & \\
\hline KE & $\begin{array}{l}\text { Increased } \mathrm{pH} \text { of gastric acid and } \\
\text { related findings }\end{array}$ & Yes & Likely & $\begin{array}{l}\text { Increased } \mathrm{pH} \text { of gastric acid is predictable because omeprazole has } \\
\text { been used for increasing the gastric acid } \mathrm{pH} \text { in humans. }\end{array}$ \\
\hline $\mathrm{KE}$ & Increased serum gastrin & Yes & Unlikely & No evidence of changing gastric secretion, except in rats. \\
\hline KE & $\begin{array}{l}\text { Increased activity of } \\
\text { proliferation of ECL cells }\end{array}$ & Yes & Unlikely & $\begin{array}{l}\text { Omeprazole-mediated ECL cell hyperplasia has been reported in } \\
\text { dogs, at a } 10 \text {-fold higher dose than that in rats. } \\
\text { No evidence of chemically-induced ECL cell proliferation/ } \\
\text { hyperplasia, except in rats. }\end{array}$ \\
\hline KE & ECL cell hyperplasia & Yes & Unlikely & No evidence of chemically-induced ECL cell tumors, except in rats. \\
\hline Outcome & ECL cell tumor induction & Yes & Unlikely & No evidence of chemically-induced ECL cell tumors, except in rats. \\
\hline
\end{tabular}

KE: key event, MoA: mode of action; ECL cell: enterochromaffin-like cell. 
excluded, due to insufficient evidence to clarify the early KE.

An adverse outcome pathway (AOP) is known as a logical sequence of causally linked events at different levels of biological organization, which follows exposure to a chemical and leads to adverse health effects in humans ${ }^{32}$. The IPCS cancer-/non-cancer-HRF is more specific to toxicity or carcinogenicity induced by a target chemical than AOP, because the outcome results from the target chemical treatment, and results of toxicological or mechanistic studies of the target chemical are used in each analytical step of the postulated MoA. Compound-specific analysis using the IPCS cancer-/non-cancer-HRF is considered suitable for toxicological assessments of MoA and human relevance conducted by regulatory organizations. In conclusion, the IPCS cancer-HRF is a very effective tool for assessing the human relevance of cancers induced by chemicals.

Disclosure of Potential Conflicts of Interest: I declare that this research did not receive any specific grant from funding agencies in the public, commercial, or not-for-profit sectors.

Disclaimer: The author states that the views, thoughts, and opinions presented here are not necessarily those of FSCJ.

\section{References}

1. FSCJ. A risk assessment reports of butachlor. 2011, from FSCJ website: https://www.fsc.go.jp/fsciis/evaluationDocument/show/kya20071012003

2. FSCJ. A risk assessment report of alachlor. 2013, from FSCJ website: https://www.fsc.go.jp/fsciis/evaluationDocFument/show/kya20130130012

3. FSCJ. A risk assessment report of acetochlor. 2013, from FSCJ website: https://www.fsc.go.jp/fsciis/evaluationDocument/show/kya20071218003

4. FSCJ. A risk assessment report of metrachlor. 2009, from FSCJ website: https://www.fsc.go.jp/fsciis/evaluationDocument/show/kya20080617001

5. FSCJ. A risk assessment report of propachlor. 2013, from FSCJ website: https://www.fsc.go.jp/fsciis/evaluationDocument/show/kya20080909002

6. Boobis AR, Cohen SM, Dellarco V, McGregor D, Meek ME, Vickers C, Willcocks D, and Farland W. IPCS framework for analyzing the relevance of a cancer mode of action for humans. Crit Rev Toxicol. 36: 781-792. 2006. [Medline] [CrossRef]

7. IPCS. Harmonization Project Document No. 4. Part1: IPCS framework for analysing the relevance of a cancer mode of action for humans and case-studies. Part2: IPCS framework for analysing the relevance of a non-cancer mode of action for humans and case-studies. 2007, from WHO website: https://www.who.int/ipcs/methods/harmonization/areas/ cancer_mode.pdf?ua $=1$

8. Meek ME, Bucher JR, Cohen SM, Dellarco V, Hill RN, Lehman-McKeeman LD, Longfellow DG, Pastoor T, Seed J, and Patton DE. A framework for human relevance analysis of information on carcinogenic modes of action. Crit Rev Toxicol. 33: 591-653. 2003. [Medline] [CrossRef]
9. Hill AB. The environment and disease: association or causation? Proc R Soc Med. 58: 295-300. 1965. [Medline]

10. JMPR. Toxicological monograph of fluopicolide, 2009, from WHO, JMPR website: https://apps.who.int/iris/bitstream/handle/10665/44522/9789241665254_eng.pdf;jsess ionid $=46 \mathrm{BFCC} 6567 \mathrm{C} 2535853 \mathrm{ACB} 8 \mathrm{~B} 5 \mathrm{C} 10 \mathrm{~A} 90 \mathrm{~F} 9$ ?sequen $\mathrm{ce}=1$

11. JMPR. Toxicological monograph of cyproconazole. 2010a, from WHO, JMPR website: https://apps.who.int/ iris/bitstream/handle/10665/44660/9789241665261_eng. pdf?sequence $=1$

12. JMPR. Toxicological monograph of fluopyram. 2010b, from WHO, JMPR website: https://apps.who.int/iris/bitstream/ handle/10665/44660/9789241665261_eng.pdf?sequence $=1$

13. JMPR. Toxicological monograph of thiametoxam. 2010c, from WHO, JMPR website: https://apps.who.int/iris/ bitstream/handle/10665/44660/9789241665261_eng. pdf?sequence $=1$

14. JMPR. Toxicological monograph of etofenprox. 2011a, from WHO, JMPR website: https://apps.who.int/iris/bitstream/ handle $/ 10665 / 75147 / 9789241665278$ eng.pdf?sequence $=1$

15. JMPR. Toxicological monograph of sulfoxaflor. 2011b, from WHO, JMPR website: https://apps.who.int/iris/bitstream/ handle/10665/75147/9789241665278 eng.pdf?sequence $=1$

16. JMPR. Toxicological monograph of fluxapyroxad. 2012, from WHO, JMPR website: https://www.who.int/foodsafety/publications/jmpr-monographs/en/

17. JMPR. Toxicological monograph of mesotrione. 2014, from WHO, JMPR website: https://apps.who.int/iris/bitstream/ handle/10665/164597/9789241665308_eng.pdf?sequence=1

18. JMPR. Toxicological monograph of acetochlor. 2015a, from WHO, JMPR website: https://www.who.int/foodsafety/publications/jmpr-monographs/en/

19. JMPR. Toxicological monograph of flonicamid. 2015b, from WHO, JMPR website: https://www.who.int/foodsafety/publications/jmpr-monographs/en/

20. JMPR. Toxicological monograph of flumioxazin. 2015c, from WHO, JMPR website: https://www.who.int/foodsafety/publications/jmpr-monographs/en/

21. JMPR. Toxicological monograph of pydiflumetofen. 2018a, from WHO, JMPR website: https://apps.who.int/ iris/bitstream/handle/10665/325787/9789241655330-eng. pdf?ua $=1$

22. JMPR. Toxicological monograph of pyraclostrobin. 2018b, from WHO, JMPR website: https://apps.who.int/ iris/bitstream/handle/10665/325787/9789241655330-eng. pdf?ua $=1$

23. Mitsubishi Tanabe Pharma 2017, Omeprazon tablet. 2017, from Mitsubishi Tanabe Pharma websites: https://medical. mt-pharma.co.jp/di/file/if/f_omp.pdf

24. Eason CT, Spencer AJ, Pattison A, Howells DD, Henry DC, and Bonner FW. Species variation in gastric toxicity following chronic administration of ciprofibrate to rat, mouse, and marmoset. Toxicol Appl Pharmacol. 95: 328-338. 1988. [Medline] [CrossRef]

25. Spencer AJ, Barbolt TA, Henry DC, Eason CT, Sauerschell RJ, and Bonner FW. Gastric morphological changes including carcinoid tumors in animals treated with a potent hypolipidemic agent, ciprofibrate. Toxicol Pathol. 17: 7-15. 1989. [Medline] [CrossRef]

26. Furukawa S, Harada T, Thake D, Iatropoulos MJ, and Sherman JH. Consensus diagnoses and mode of action for the 
formation of gastric tumors in rats treated with the chloroacetanilide herbicides alachlor and butachlor. Toxicol Pathol. 42: 386-402. 2014. [Medline] [CrossRef]

27. Heydens WF, Wilson AGE, Kier LD, Lau H, Thake DC, and Martens MA. An evaluation of the carcinogenic potential of the herbicide alachlor to man. Hum Exp Toxicol. 18: 363-391. 1999. [Medline] [CrossRef]

28. Graves P. 8. Digestive system. In: Histopathology of Preclinical Toxicity Studies, 4th ed. P Graves (ed). Academic Press, Amsterdam. 325-432. 2012.

29. Nolte T, Brander-Weber P, Dangler C, Deschl U, Elwell MR, Greaves P, Hailey R, Leach MW, Pandiri AR, Rogers A, Shackelford CC, Spencer A, Tanaka T, and Ward JM. Non-proliferative and proliferative lesions of the gastroin- testinal tract, pancreas and salivary glands of the rat and mouse. J Toxicol Pathol. 29(Suppl): 1S-125S. 2016. [Medline] [CrossRef]

30. Delle Fave G, Marignani M, Moretti A, D’Ambra G, Martino G, and Annibale B. Hypergastrinemia and enterochromaffin-like cell hyperplasia. Yale J Biol Med. 71: 291-301. 1998. [Medline]

31. Yakata M. 9. Hormone measurement. In: Mechanisms of Abnormal Value, 5th ed. T Kawai, M Yakata, and Y Itoh (eds). Igaku-shoin, Tokyo. 275-366. 2009 (in Japanese).

32. OECD. OECD Series on Adverse Outcome Pathways. from OECD website: https://www.oecd-ilibrary.org/environment/oecd-series-on-adverse-outcome-pathways_2415170x 